\title{
O IIINERÁRIO DA ANTROPOLOGIA URBANA DO PONTO DE VISTA DA JORNADA DE UM AUTOR: UMA CONVERSA COM RUBEN GEORGE OLIVEN'
}

\section{Ana Luiza Carvalho da Rocha}

\section{Universidade Federal do Rio Grande do Sul - Brasil}

Resumo: Entrevista com o Prof. Dr. Ruben George Oliven, Coordenador do PPGAS/ UFRGS, a respeito de sua trajetória acadêmica e produção intelectual no âmbito da antropologia urbana.

Palavras-chave: antropologia urbana, cidade moderna, história da antropologia.

Abstract: Interview with Prof. Ruben George Oliven, Ph.D, Chair of the Graduate Program in Social Anthropology of the Federal University of Rio Grande do Sul, about his academic career and his studies and publications on urban anthropology.

Keywords: history of anthropology, modern city, urban anthropology.

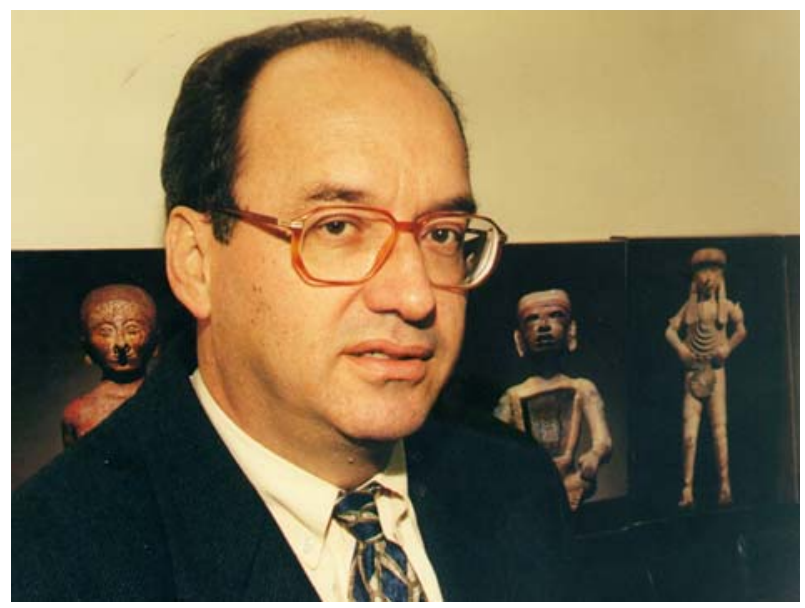

Foto: Cristina Lima - acervo pessoal professor Ruben G. Oliven

1 A produção deste texto só foi possível graças ao acolhimento que recebemos do Prof. Ruben George Oliven, em sua casa, num dia de semana, à noite, ao fim de sua jornada de trabalho. Agradecemos aos 
Ana: Ruben, gostaria de começar a entrevista te pedindo que nos contasses um pouco a respeito das origens de tua formação acadêmica.

Ruben: Eu me formei em Ciências Sociais, na UFRGS, em 1968. Era uma época de uma certa efervescência política, do golpe de 1964, do AI 5..., e havia alguns temas que eram muito candentes em Ciências Sociais. Temas que diziam basicamente respeito ao funcionamento da sociedade brasileira em que eram usados conceitos eminentemente sociológicos, muito amplos, como os conceitos de Estado, luta de classes, desenvolvimento, dependência, partidos, sindicatos, ideologia... Estes eram os grandes temas do momento, e os cientistas sociais que se dedicavam a estudar a sociedade brasileira trabalhavam com este tipo de problemática. Havia coisas que não eram consideradas temas tão importantes, por exemplo, os temas ligados às sociedades indígenas estudados por antropólogos, mas que não eram uma problemática das pessoas que estavam pensando o Brasil, isto era uma coisa que estava mais distante. Os fenômenos que faziam parte da cultura brasileira não eram uma temática privilegiada, eram pouco estudados. Havia, na época, um certo esquematismo nas Ciências Sociais, pois se pensava que, ao se compreender o funcionamento econômico da sociedade, automaticamente se entenderia a cultura e que ela seria quase uma conseqüência dos fatos econômicos. Também havia certa desconfiança em relação a qualquer explicação que fosse culturalista, isto é, a sociedade não poderia ser explicada a partir da cultura, ela sempre tinha que ser explicada a partir da economia e a partir da posição que as pessoas ocupavam no processo produtivo. Mais ou menos assim: se tu queres saber como as pessoas pensam, tu tens que descobrir onde elas estão na estrutura ocupacional, pois dela derivaria tua consciência de classe, tuas formas de pensar e se organizar. Então tinha um caminho que era quase canônico de descobrir a realidade. E muito destes processos que estavam sendo discutidos estavam acontecendo no contexto urbano. Eram processos que estavam relacionados com coisas que aconteciam em cidades. Na época, havia relativamente poucas teorizações sobre a cidade, apenas alguns estudos sobre a cidades e que tinham um cunho mais sociológico. Não se chegava, assim, a se teorizar o fenô-

nossos bolsistas de iniciação científica CNPq/FAPEGRS, Rosana Pinheiro Machado, Rodrigo Mercio, João de los Santos, Olavo Ramalho Marques, Débora Leitão, pela cuidadosa transcrição e a Rafael Victorino Devos, pela dedicação no registro audiovisual da entrevista. À Arabela Oliven, agradecemos pelos cafezinhos e as deliciosas bolachinhas que nos mantiveram despertos e felizes.

Horizontes Antropológicos, Porto Alegre, ano 6, n. 13, p. 219-249, jun. 2000 
meno urbano. Isto é, havia estudos a respeito dos diferentes grupos que moravam na cidade, mas a abordagem era sempre em torno do processo de desenvolvimento econômico. Estes estudos relacionavam-se com o contexto das cidades uma vez que o Brasil estava, na ocasião, se urbanizando rapidamente. Mas a cidade como tal não chegava a ser um objeto privilegiado de estudo. Foi neste ambiente intelectual que eu me formei em Ciências Sociais. Era um contexto muito estimulante, pois participava de debates, lia muitas coisas..., mas eu sempre tinha uma certa insatisfação porque, no fundo, os temas que eu achava interessante eram os temas da cultura, ou seja, por que as pessoas são como são? Por que vivem de um determinado modo? Porque pensam de uma certa forma? Eu estava interessado nisso e, mais que isso, eu tinha uma certa preocupação de entender como funcionam as cidades. O que vem a ser, afinal, uma cidade? Bom, muitas destas respostas queria obter e eu fui começar a estudar. Comecei a tomar contato com estudos que havia naquela época, muitos trabalhos na área da sociologia urbana, principalmente nos Estados Unidos, na França... No Brasil, a antropologia estava começando, em algumas partes, a estudar a sociedade brasileira em seus rituais, muitos estudos sobre carnaval, religião..., mas ainda não se chegava a ter uma teorização sobre o tema. Embora fosse uma tendência, este era um pouco o clima nos anos 70. Lembro-me que, na época, eu resolvi fazer uma espécie de programa de estudos para mim. Eu comecei a trabalhar na UFRGS e, então, decidi organizar um seminário sobre fenômeno urbano, comecei a procurar bibliografia sobre o assunto.

Ana: Um seminário no âmbito da UFRGS?

Ruben: Sim, no âmbito do curso de Ciências Sociais, que era um curso de graduação; na época, não havia ainda pós-graduação, que só foi surgir mais tarde. Então, eu comecei a olhar uma bibliografia e havia, assim, algumas coisas traduzidas de Georg Simmel, da Escola de Chicago. Era basicamente um livro chamado O Fenônemo Urbano, organizado por Otávio Velho e que foi publicado pela Editora Zahar em 1967. Este livro era composto de cinco ou seis ensaios, era um livro muito útil, uma boa seleção de ensaios. Tinha o ensaio clássico do Simmel sobre a metrópole e a vida mental, o ensaio de Max Weber sobre conceito e categorias de cidade, um artigo de Robert Ezra Park, contendo sugestões para a investigação do comportamento humano no meio urbano, um artigo clássico do Luís Wirth sobre o urbanismo como forma de vida. Estes dois últimos autores faziam parte da chamada Escola de Chicago, que estudou 
a cidade na primeira metade do século passado. Era uma seleção que abria os horizontes, e eu comecei a estudar um pouco essa bibliografia. Ao mesmo tempo, decidi fazer um curso de mestrado que tinha recém-surgido, o Mestrado em Planejamento Urbano, porque, após me formar, eu trabalhei em planejamento em diferentes empresas; então, tinha uma certa experiência e, ao mesmo tempo, estava interessado no urbano. Comecei a escrever coisas sobre o assunto, e acabei produzindo meus dois "pecados de juventude”... São dois livros que estão esgotados, publicados pela Editora da UFRGS: o primeiro se chamava Educação e Sociedade Moderna e tem como subtítulo "Funções da Educação no Contexto Urbano”, já que procura justamente discutir qual seria a função da educação no contexto urbano.

Ana: Isto foi em 1972, não?

Ruben: O livro foi publicado em 72, mas escrito em 70. Em 1971, eu procurava discutir o que era o contexto urbano, como é que as pessoas pensavam, como é que elas tinham informação, o papel da educação nas relações entre a cidade e a sociedade rural. Logo em seguida, publiquei um outro livro, um conjunto de artigos que acabou recebendo o título de Metabolismo Social da Cidade.

Ana: Estamos, então, em 1974.

Ruben: Isto mesmo. Eu acabei usando um termo que era o termo biológico de metabolismo, como se a cidade tivesse um metabolismo. Foi um artigo que escrevi que deu nome ao livro, ele se chamava "Metabolismo Social da Cidade" e era uma discussão a respeito de um assassinato que houve em Nova York e como as pessoas não reagiram e tal...

Ana: Ah, eu me lembro de ter estudado este artigo quando ingressei nas Ciências Sociais...

Ruben: Era esse aí... E depois produzi uma série de outros artigos que foram publicados posteriormente e discutiam o tema da cidade. Um deles era sobre cultura e personalidade, o outro era um artigo em que fazia uma análise do mito de Abel e Caim, referenciando-o ao surgimento da cidade na época bíblica. Minha intenção era mostrar como a primeira cidade que surge na Bíblia está associada ao tema de um assassinato, de um fratricídio e que, portanto, a cidade na tradição ocidental aludia à maldade, ao perigo... Depois, ainda tinha um outro ensaio sobre a América Latina, educação e desenvolvimento..., não estou 
lembrado mas deve ter um outro artigo ainda. Então, essas eram as teorizações de quem estava começando, tinha lido alguma coisa, tinha muita imaginação, mas relativamente pouca informação.

Ana: Em termos teóricos e conceituais, o que tu buscavas, precisamente, nessa época?

Ruben: Eu buscava duas coisas. Uma delas, que eu buscava desde o começo, era uma aposta numa espécie de disciplina intelectual. Isto é, iria começar a produzir textos a partir das idéias que eu estava pensando. O que iria pesquisar resultaria em alguma coisa escrita, o que me obrigava a um compromisso e, ao mesmo tempo, me possibilitava publicar. Ou seja, tornar público aquilo que eu estava fazendo com a finalidade de discutir com as pessoas. Então, isso era uma forma de trabalho que adotei desde que comecei a me aprofundar sobre o tema da cidade; uma forma de trabalhar e produzir que eu sempre mantive, obviamente me dando conta de que tudo o que se escreve é datado, não no sentido de que os textos muitas vezes ficam desatualizados, mas no sentido de que um texto sempre é produzido num determinado tempo e contexto. Se não colocar no papel aquela idéia que estou pensando no momento, dez anos depois é que eu não vou escrevê-la, porque eu estarei pensando outra coisa.. E eu nunca me arrependi de fazer isto, porque acho que isso me possibilitou ir adiante, fazer coisas melhores justamente porque fiz coisas que não eram tão boas em momentos anteriores. Então era isso, desbravar um campo intelectual... Até lá não tinha feito pesquisa ainda. Eu tinha que fazer uma dissertação de mestrado, que naquela época se chamava "tese de mestrado". A segunda coisa é que decidi, então, fazer um estudo que tinha como tema teórico a cidade como local de integração. Eu estava começando a teorizar, queria entender a cidade como um contexto onde aconteciam fenômenos singulares, mas também um local no qual as pessoas, principalmente aquelas que vinham de fora, se integravam ou não se integravam. Estava realmente preocupado com isso, o que também era algo que a literatura discutia muito, ou seja, se as populações que eram faveladas ou marginais, eram faveladas ou marginais, porque tinham "problemas culturais", uma vez que elas vinham de outro contexto, partilhavam valores rurais; ou se sua situação de vida tinha por causa a situação social e econômica do país que impedia que elas se integrassem. Isto era um debate que havia o tempo inteiro e estava ligado ao tema da marginalidade urbana, que é um tema que comecei a estudar também. Então, para minha dissertação eu 
fiz um longo estudo teórico sobre o tema e escolhi um lugar para realizar a pesquisa. Era a Vila Farrapos, uma vila perto do Aeroporto Salgado Filho, que tinha sido criada há pouco tempo. Esta vila havia sido planejada e eu decidi estudá-la. Fiz uma pesquisa que combinava diferentes técnicas e procedimentos: entrevistas pessoais... e, ao mesmo tempo, apliquei uma série de questionários com alunos. Eu procurava, assim, olhar, sob vários aspectos, esta vila: trabalho, família, vida associativa, religião, etc. Queria ter uma idéia mais abrangente de sua população, queria ver como é que funcionava sua vida. E eu aprendi muito ali. Aprendi como fazer uma amostra, como entrevistar, entrar na casa das pessoas, o que se pode, o que não dá para perguntar...

Ana: Nesta época, quem era teu orientador?

Ruben: Na verdade, eu tive três orientadores. Aliás, nunca ficou bem claro qual dos três era meu orientador. Um deles era o Prof. Herbert Calháu, da Estatística, e que me ajudou em toda a parte de amostra e parte quantitativa; a outra era a Profa Dóris Müller, que era urbanista e entendia muito do tema, e havia ainda um professor visitante, o sociólogo norte-americano David Hansen, que dominava a discussão sobre modernização. Eu me orientava com os três, mas nunca com todos juntos, só no final. Depois, eu tomava as decisões, incorporava aquilo que achava que tinha que incorporar, e isto funcionou bem. No final, me dei conta que eu tinha mapeado a discussão sobre a cidade e que tinha incorporado outros autores além de sociólogos. Havia trabalhado com textos de antropólogos como Robert Redfield e outros que tinham estudado grupos populares. Tinha entrado em contato com uma literatura antropológica, em outras línguas, que era bastante rica; autores que estavam pensando questões parecidas com as minhas. Bom, percebi que este segmento social da Vila Farrapos, se me perguntassem se eles estão integrados ou não estão integrados ao contexto urbano, eu diria que estão integrados. São pessoas que moram numa vila, mas trabalham noutros lugares, então conhecem a cidade. Terminei minha dissertação, por um lado, satisfeito com o que eu tinha feito, mas, por outro lado, continuava com uma pergunta que não conseguia responder: como é que essas pessoas são em relação a outros grupos urbanos? Esta resposta eu não tinha porque não conhecia outros grupos. Eu podia falar muito sobre o grupo que havia estudado, mas não podia compará-lo com outros grupos. Neste momento, decidi ir um pouco mais adiante, quer dizer, resolvi problematizar mais a parte teórica que havia construído. Comecei a incorporar novos autores e acabei entrando numa discussão sobre cultura. Aí, eu bolei um outro seminário, 
também no curso de graduação, que tinha que ver com "Cultura e Comunicação”. Era um seminário sobre a cultura. Mais tarde criei outro seminário sobre "Mudanças Culturais". Eu basicamente selecionava a bibliografia que me interessava, lia com os alunos e discutia. Aí, notei que a bibliografia colocava um problema que nunca conseguia resolver: afinal as pessoas que vivem em cidades, ou que vivem numa sociedade predominantemente urbana, são ou tendem a ser parecidas entre si, ou não? Na época, havia duas correntes opostas: uma corrente dizia que estava havendo um processo de modernização, isto é, modernização como sinônimo de ocidentalização, o que faria com que as pessoas passassem a ter valores cada vez mais semelhantes, que era só uma questão de tempo e que isto apareceria nas roupas, nos costumes, nos tipos de família, na secularização e, lentamente, isto se espalharia para o mundo todo. O Brasil seria um exemplo disso. Os autores desta tendência se fossem pensar hoje a figura do gaúcho diriam que ele iria desaparecer, pelo menos nas grandes cidades. Realmente, em Porto Alegre, naquela época, não se via ninguém vestido de gaúcho...

Ana: Desculpa te interromper, mas tu falaste, só para fazer um "gancho", o que acontecia, na época, no Brasil que permitia que se pudesse pensar que a figura do gaúcho não iria acabar, ou coisa assim?

Ruben: Essa é uma boa pergunta. Acho que havia duas coisas simultaneamente. Vivíamos no período da ditadura e havia uma tendência forte de centralização do Estado. O governo federal tinha um poder bastante grande sobre programas de televisão, sobre o rádio, sobre a educação e currículos. O regime militar veio depois de 1964, promoveram uma maior unificação do Brasil. Se a Revolução de 30 significou uma unificação econômica e cultural, a Revolução de 64 significou uma nova unificação. Isto é, muita centralização econômica, integração de mercados, criação de redes de comunicação, estradas, telefonia, e tudo isso significava uma integração maior, havia uma ideologia muito forte em torno do Brasil, do tipo "ame-o ou deixe-o", ganhar a Copa do Mundo ... Não havia muito espaço para a diferença. Mas não só por causa da ditadura, mas devido a todo um ambiente voltado para construir o Brasil. Então, a idéia da diferença não era muito enfatizada, nem era uma coisa muito discutida nas Ciências Sociais, até porque as pessoas mais críticas falavam contra a ditadura, mas nunca com uma idéia de apontar diferenças, porque isto poderia enfraquecer uma posição política. Não havia espaço, por exemplo, para movimentos feministas, movimentos homossexuais tampouco, enfim, tudo que apontasse para diferenças no Brasil era relativamente perigoso. Eu quase diria que há 
uma tendência no Brasil de tudo que aponta para diferenças ser olhado com uma certa desconfiança, como se as pessoas tivessem que pedir desculpas pelo fato de serem diferentes.

Ana: E tu andavas, na época, meio na contramão, não estavas satisfeito com o fato do que tu sabias como era um determinado grupo urbano, mas não sabias diferenciá-los de outros que habitavam a cidade ...

Ruben: Até pelo fato de ser filho de imigrantes, eu sempre fui muito sensível à diferença. Eu sempre tive, desde pequeno, que lidar com grupos diferentes, conviver com várias comunidades diferentes. Ao transitar por isso fui me dando conta de que isso no Brasil era meio complicado. Era um pouco assim... "o país te acolhe, mas, muito bem, tu tens que ser igual aos outros”, e eu sempre percebia... "bom, as pessoas não são iguais aos outros, têm vários tipos de identidade, filiações, lealdades, etc.” Mas havia, como estava comentando, uma outra corrente teórica, era uma literatura a qual estava me referindo em relação à cidade e que ia no outro sentido. Enfatizava muito a questão das diferenças e dizia que as pessoas são diferentes e que a cidade tende a promover uma diferenciação muito grande... Então esse era o debate no qual me situava, e eu não percebia muito bem como esse debate se resolvia. Esse debate se refletia em várias outras coisas, por exemplo, a discussão sobre a marginalidade... Aí, comecei a estudar a marginalidade urbana, e a primeira coisa que notei foi que havia três tipos de literaturas sobre a marginalidade que não dialogavam entre si: a econômica, com economistas e sociólogos discutindo as causas da marginalidade e debatendo se o fenômeno da marginalidade existia porque existia o imperialismo, ou se a marginalidade existia independente do imperialismo, mas em razão do desenvolvimento ser intensivo em capital e não absorver mão de obra. Uma discussão enorme, extremamente técnica, que eu li toda; a outra literatura enfatizava os aspectos políticos da marginalidade, era sobre a questão da marginalidade e o comportamento político dos favelados; os cientistas sociais escreviam sobre o assunto e faziam uma discussão sobre voto e favela, sem praticamente nenhum diálogo com os economistas; e outra literatura, ainda, que abordava o tema da marginalidade cultural, onde os antropólogos se encontravam, como os estudos de Oscar Lewis sobre a cultura da pobreza, por exemplo. Então, novamente, para variar, resolvi reunir estas tendências que não dialogavam e acabei produzindo um artigo denominado "Marginalidade Urbana na América Latina: Aspectos Econômicos, Políticos e Culturais”, ten- 
tando reunir os três aspectos apontados, produzindo uma "salada" minimamente palatável.

Ana: Tu tens listado em tuas obras, nesta época, o artigo "A heterogeneidade da homogeneização: ou de como nem todos os habitantes de Porto Alegre são iguais”, publicado em 78 .

Ruben: Era aí que eu queria chegar. Para resolver essas questões todas eu decidi fazer uma pesquisa mais ampla, em que decidi comparar vários grupos. Resolvi, então, fazer uma pesquisa, na qual inclusive tu participaste na época em que eras minha aluna no curso de Ciências Sociais, e que abrangia cinco grupos urbanos situados em cinco locais diferentes: um era a favela Vila Maria da Conceição, uma das mais antigas favelas de Porto Alegre; o segundo era Navegantes, que é um bairro originalmente operário, bem marcado, com um time de futebol, festa típica, a Festa de Navegantes; o terceiro era a Cidade Baixa, um bairro que historicamente tu conheces muito bem, marcado por uma relação com a "cidade alta", sendo primeiro um lugar de ex-escravos, mais tarde, bairro de classe média e que vai sofrendo sucessivas mutações, mudando o seu perfil embora mantendo parte da sua antiga arquitetura; o quarto era o bairro Petrópolis, onde atualmente moro, que nasceu, originalmente, na década de 40, um bairro de classe média; e o quinto, e último, era o bairro Três Figueiras, o mais elegante da época, mais aristocrático. Eu resolvi escolher esses bairros propositalmente. Resolvi que eu não ia escolher classes sociais ... não vou pegar marginal, operário, funcionário público, bancário, etc., vou fazer outro recorte para sair do tradicional. Mas vou estar atento para características como renda, escolaridade, capital cultural ... e resolvi que eu compararia estes grupos a partir de várias áreas que eu chamei de "áreas de envolvimento": família, educação, trabalho, religião, vida associativa e política. Eu queria estudar a questão do ser diferente por isto não podia pegar um aspecto só. Foi uma pesquisa que envolveu questionários, entrevistas abertas, visitas aos bairros, etc. E resolvi usar este material para produzir minha tese de doutorado na Universidade de Londres. Então, levei este material para Inglaterra e lá me deparei com uma nova mudança... eu havia saído de um país, estava vivendo uma ditadura militar e passei a viver num país onde a liberdade era total. Eu ficava pasmo que as pessoas não precisassem usar a carteira de identidade na rua... era uma coisa que eu tinha dificuldade, nos primeiros dias, de sair sem a carteira de identidade. Vivia me apalpando, pois faltava alguma coisa. Lá o 
debate era livre, as pessoas podiam dizer o que quisessem, uma coisa que, no Brasil, em 74, era extremamente complicado. Fui morar numa grande cidade, em Londres, num ambiente intelectual estimulante, com debates, bibliotecas fantásticas... Eu, então, passei um bom período lendo, indo a todo tipo de debate, participando nos mais variados grupos, aprendendo muito, abrindo horizontes... e tendo uma experiência com uma vida intelectual diferente da que havia no Brasil...

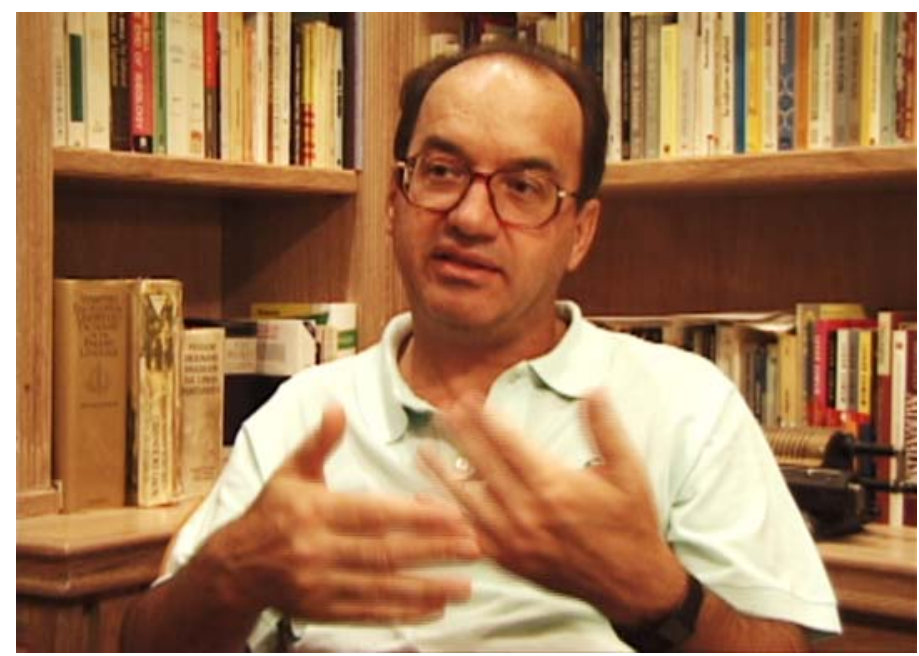

Ana: Como foi o teu período em Londres diante das tuas preocupações com a questão da diferença no contexto urbano da sociedade brasileira?

Ruben: Depois que passou a fase de deslumbramento, comecei a trabalhar os dados de pesquisa e acabei, publicando a tese no Brasil, pela Editora Vozes, como nome de "Urbanização e Mudança Social no Brasil”. O que ela expressa, fundamentalmente, era como nem todos habitantes de Porto Alegre eram iguais; os dados mostravam que os meus entrevistados eram muito semelhantes em algumas áreas e muito diferentes em outras. As pessoas de grupos mais simples tendiam a ter, por exemplo, um modelo de família bem mais hierarquizado. Disciplina era disciplina, hierarquia era hierarquia, poder era poder. Havia uma distinção entre o que os pais e os filhos faziam. Havia uma idéia clara de que 
quem devia trabalhar fora era só o marido, mesmo que a mulher estivesse trabalhando era em razão da necessidade. Era um modelo bem mais tradicional. Nos grupos das classes médias, havia um modelo individualista, democrático, onde todos são iguais, podem opinar, mesmo que no dia-a-dia ocorresse a manipulação, esse era o discurso. E, assim, coisas muito interessantes ... Na área da religião, havia pessoas que achavam que Deus não só criou o mundo, mas continuava cotidianamente intervindo nele. Assim, todas as coisas que aconteciam no mundo se deviam à interferência direta de Deus no mundo. Em grupos mais secularizados, quem acreditava em Deus achava que ele era arquiteto do mundo, mas não intervinha diariamente nas coisas que estavam acontecendo. Na política, havia também uma clivagem muito grande. Havia toda uma discussão do voto do analfabeto, se ele, o povo, sabia votar ou não... na época era difícil fazer perguntas políticas. Mas os grupos populares claramente achavam que eles sabiam votar, que deveriam ter direito a voto, grupos das elites tendiam a achar muito menos isso. Então, isto tudo acabou fazendo com que eu desenvolvesse uma idéia de que há homogeneização em algumas áreas da vida urbana, mas não em outras, dependendo de quais são as áreas e do que isto significa. A urbanização não era, assim, um processo único, unitário, ela tinha diferentes facetas, e viver na cidade significava ter uma série de especificidades no que se refere aos grupos sociais. Naquele tempo ainda não se trabalhava com o conceito de identidade, mas depois isto veio a ser a questão da identidade de diferentes grupos.

Ana: Comenta um pouco sobre os autores que te influenciaram nesta época, e as mudanças em tuas perspectivas teóricas.

Ruben: Bom, a Inglaterra, do ponto de vista acadêmico, significou várias coisas. Naquele tempo havia, no Brasil, dois modelos de influências muito marcantes. Em parte, foi por isso que eu fui para a Inglaterra, não estaria sujeito a nenhum dos dois modelos. Um era o modelo francês traduzido, no Brasil, de forma excessivamente retórica, era quantidades de palavras enormes, frases difíceis de entender. Confesso que tinha uma certa dificuldade e ficava pensando “não daria para escrever mais fácil?”. Além disso, eu não conseguia escrever tão difícil! Então, tinha frases naquela época, que tu deves te lembrar... sempre que se falava em sociedade, se falava em "sociedade inclusiva”. E aí eu pensava: "existe sociedade exclusiva? A sociedade não é inclusiva por definição?”. Havia uma série de palavras que não significavam 
muito, era um estilo muito retórico. O outro era um estilo, assim, muito quantitativo e que vinha dos Estados Unidos ... tudo tinha que ser medido, toda hipótese deveria ser testada. e que não levava a uma explicação muito grande. A Inglaterra, assim, significou para mim um rigor muito grande no escrever. A primeira coisa que eu me dei conta foi quando comecei a escrever em português e a traduzir para o inglês. Isso não funcionava porque a maneira de construir é completamente diferente. Então, decidi que eu ia escrever tudo em inglês. E aí, em geral, era assim: "O que é que tu queres dizer com isso? Não estou entendendo.” O orientador dizia isso com a maior naturalidade, então, isso me obrigou a escrever de tal maneira que as pessoas conseguissem entender. Havia também uma cobrança muito grande em torno de rigor, quer dizer, um pouco na tradução empiricista inglesa:, "Olha, mas tu não tem fatos para dizer isso, logo isto não é evidente”. Isso aparecia inclusive, por exemplo, entre os marxistas ingleses. Acompanhei o debate entre Hobsbawm e Thompsom sobre "se o metodismo impediu ou não a Revolução na Inglaterra”. Eles discutiam com o rigor dos dados, olhando os dados sobre metodismo em cada região da Inglaterra. Então, mesmo entre os marxistas ingleses havia uma preocupação de calcar tudo o que diziam em cima de algum material que pudesse validar aquele tipo de afirmação. Isso foi uma formação muito importante para mim, um pouco a questão da objetividade. Depois, na época, entrei em contato com vários autores ingleses, sendo que alguns eu já conhecia, como Raymond Williams. Eu li muito sobre a história da Inglaterra, li Thompson, Hill, Hobsbawm. Decidi, assim, aproveitar, não só para trabalhar na tese, mas para aprofundar mais extensivamente vários assuntos que me alargariam os horizontes. Havia os próprios antropólogos ingleses; fiz cursos com Ernest Gellner, um dos maiores especialistas na questão do nacionalismo, assisti palestras de Mary Douglas... Foi uma experiência de sair do país, de ir para outra cultura, onde se trabalha diferente... O clima intelectual também foi uma coisa que me ajudou porque tinha muita gente com quem eu debatia, participava de muitos seminários em lugares diferentes. Bom, também me dei conta, quando estava terminando a tese, que eu não tinha mais coisas para ler sobre urbanização... descobri que cada vez que eu lia um artigo e que lia a bibliografia, reconhecia 95\% dos artigos citados. Aí decidi que quando voltasse para o Brasil não iria me ocupar com cidade propriamente dita, ia me interessar pela questão da cultura brasileira, como se essas coisas fossem separadas... Vivendo quatro anos fora do Brasil, eu pensei muito no Brasil. Logo que terminei a tese, publiquei um artigo 
que era uma espécie de programa de pesquisa para a minha volta, chamava-se “Classe e cultura em cidades brasileiras”. Então, lá mesmo, na Inglaterra, comecei a ler sobre esse assunto e a discutir a forma como as diferentes classes sociais se comportam em relação à cultura no Brasil. Foi um artigo, escrito e publicado em inglês e depois publicado no Brasil. E aí, voltei para o Brasil e me deparei com uma realidade completamente diferente. Eu regressei no começo da abertura política.

Ana:É interessante se observar os “insights” que tu tiveste lá fora, na Inglaterra, pois tu retornas ao Brasil justamente num período em que se começa aqui, com a redemocratização, a se revirar, mais uma vez, o tema de nossas “raízes”...

Ruben: Pois é, eu não sei se tive um insight ou foi sorte, ou as duas coisas. Eu me dei conta que a cultura brasileira era um tema importante e que tinha muito pouca coisa escrita sobre o assunto. Então eu estava, basicamente, me dizendo "é preciso estudar isto". O título do artigo que escrevi era "Classe e cultura em cidades brasileiras". Quer dizer, queria estudar este assunto nas cidades brasileiras ... voltei para o Brasil, e o Brasil começou a mudar naquele momento. Era o começo da abertura, tímida, mas era interessante que as pessoas começavam a falar sobre coisas que quatro anos antes não ousavam falar: política, contestação ... O Gabeira volta do exílio vestindo sunga de crochê... Estava tudo começando a aparecer, os partidos políticos tentando se reorganizar, as pessoas voltando do exílio, movimentos feministas, o movimento gay, donas de casa lutando contra a carestia, a luta pelo verde. Tudo isso começa a "pipocar”... Um tema sobre o qual não se falava em 1974 quando saí do Brasil era a violência urbana. Mas quando voltei em 1978 todo mundo falava sobre isso e eu fui, de alguma maneira, convocado para esse debate porque diziam assim: "Tu fizeste uma tese sobre urbanização. O que tu tens a nos dizer sobre a violência urbana?” Eu acabei, então, produzindo alguns trabalhos sobre o tema que discutiam justamente por que se falava tanto sobre a violência urbana e não se discutia a violência no campo. A violência era rotulada de "urbana”, era uma violência relacionada a assaltantes e trombadinhas. Nunca se falava das conseqüências dos golpes nas bolsas de valores, inclusive, cheguei a mostrar que os golpes nas bolsas de valores, em dois meses de um ano, eram vinte vezes maior que o total do dinheiro obtido em assaltos produzidos nos doze meses deste mesmo ano. Entrei, um pouco, nessa discussão com jornalistas, políticos, delegados de polícia. 
Ana: Tu já estavas, na época, discutindo a cultura brasileira e entrando no famoso debate em torno de se as "idéias estão no lugar" ou se "estão fora do lugar”...

Ruben: Este era um tema que, de algum modo, estava relacionado com o da cultura. Novos grupos estavam surgindo e, em última análise, construindo novas identidades, constituindo-se em atores sociais e proclamando que eles eram diferentes uns dos outros. Bom, aí reiniciam-se os diálogos dos antropólogos com sociólogos e cientistas políticos, que era muito interessante porque eles, na época, diziam: "Pois é, a cultura está sendo um fenômeno muito importante, o que se faz com a cultura?”. Na ocasião, eu respondia: “Olha, a cultura não é uma doença, não é um móvel que tu tens que botar em algum lugar: a cultura se vive”. Daí em diante, começo a notar que a comunidade antropológica tinha crescido muito; esse é o momento em que os antropólogos começam a surgir com toda a força porque eles sabiam como lidar com as questões culturais. Eles falavam de futebol, de televisão, de prostitutas, de gays... o que quer que fosse. A antropologia já possuía uma tradição de estudos na área e estava mais à vontade com os temas novos muito mais que aqueles cientistas sociais que estavam acostumados a pesquisar sindicatos e partidos, coisas que ressurgiam, mas através das quais eles conseguiam chegar, quando muito, aos movimentos sociais. Neste momento, fiz duas coisas. Uma foi produzir alguns artigos sobre cultura no Brasil, sobre o que chamei no título de um artigo de "as metamorfoses da cultura brasileira”, onde discuto a questão da apropriação de manifestações culturais específicas a certos grupos e sua transformação em símbolos nacionais. Depois, produzi outro artigo sobre a identidade brasileira .... Quando voltei da Inglaterra, descobri um tesouro na casa dos meus pais ... eram discos de 78 rotações de música popular brasileira dos anos trinta e quarenta que eles gostavam muito de ouvir quando eu era pequeno. Vi que eu poderia ir trabalhando sobre este tema, que é uma coisa que trabalho até hoje. O primeiro texto sobre música popular brasileira que produzi chama-se “A Malandragem na Música Popular Brasileira”. Juntei estes artigos sobre violência e sobre cultura num livro chamado Violência e Cultura no Brasil, também publicado pela Editora Vozes. No prefácio, escrevi que o livro tinha duas partes que tratavam de dois assuntos diferentes. A primeira parte, sobre violência, a segunda, sobre cultura. Mas, todas as pessoas que leram o livro e debateram comigo me disseram: "Só tu que achas isso porque estes temas estão relacionados". Eu realmente não tinha me dado conta disso. 
Ana: Começa, então, a se consolidar teu campo de pesquisa sobre fronteiras culturais e o estudo das cidades no Brasil porque toda tua obra mais recente se situa nesta perspectiva, derivando para o caso particular das diferenças culturais, Brasil, Rio Grande do Sul ...

Ruben: No começo, quando retornei, num primeiro momento, estou estudando a cultura brasileira, quero entender o Brasil, como funciona esta sociedade. Porque, afinal, se discute tanto a questão da identidade nacional, e a música que vou estudar é justamente a música feita no Rio de Janeiro, o samba. Por conseguinte, música nacional. Então essa é a minha tentativa.

Ana: Tu retornas ao que tu já havias pensado antes, só que ampliando e complexificando alguns de teus antigos temas de estudos (democracia, cidade, Estado), reorientando o debate das questões culturais tensionadas com os meios de comunicação.

Ruben: Retornando à questão que tu tinhas falado, a minha preocupação passa a ser um estudo mais qualitativo da cidade. Quer dizer, aquele texto a que tu te referias, "Por uma antropologia em cidades do Brasil”, que eu fiz para o livro organizado pelo Gilberto Velho, "Desafio da cidade”, era, novamente, uma espécie de plataforma para o estudo antropológico das cidades brasileiras.

Ana: Assim é que tu vais ir avançando no aprofundamento da questão das diferenças culturais e da cidade, deslocando teu eixo de reflexão, progressivamente, para as questões do nacional e do regional. Me fala um pouco deste teu percurso nos anos 80 .

Ruben: O meu percurso... ele é assim. Quando eu volto da Inglaterra, entro em um outro ambiente político. O país está fortemente interessado em política, com a redemocratização, e isto nos dois sentidos, da política partidária e das políticas em geral, culturais, sexuais, regionais, religiosas, etc. E de alguma maneira eu sou convocado para este debate, porque me convidam, o tempo inteiro, os meios de comunicação e outras áreas para o debate. Bom, resolvo entrar no debate nacional, de alguma maneira a antropologia entra no debate, chamando a questão para as diferenças no fato de, no Brasil, haver uma enorme dificuldade de se pensar a diferença, sendo ele um país com muita diversidade cultural. Entro, então, na questão dos meios de comunicação, como é preciso olhar para tais meios não só do ponto de vista da produção da mensa- 
gem, mas de como a mensagem é recebida diferentemente. Quer dizer, resolvo utilizar os ensinamentos da antropologia para entrar em um debate que é nacional. Não num debate político partidário, mas num debate sobre as questões brasileiras em última análise. Mas eu não estou sozinho nisto. Boa parte dos antropólogos brasileiros estavam fazendo o mesmo, quer dizer, "olha o que vocês estão mostrando sobre o Brasil, nós temos um monte de coisas para dizer e queremos debater com outras áreas”. Então, é um pouco, assim. É uma afirmação da antropologia, dizendo "olha, nós temos instrumentos para discutir a sociedade brasileira e nós temos condição de dizer, inclusive, o que a gente acha que está errado, como é que a gente acha que deveria ser, quais são os grupos que não têm sido ouvidos”... Isso é um diálogo constante com jornalistas e políticos e com outras áreas. É um período em que o antropólogo vira uma espécie de intelectual público, querendo ou não. Mesmo que se dissesse não para a metade dos convites, ainda tinha a outra metade. Havia demanda em torno da produção antropológica. Então, em parte, é isso. Como é que eu entro nessa questão regional? É uma coisa interessante. Quando começo a discutir a cultura brasileira, outras pessoas estão interessadas no mesmo assunto. Ajudei a criar na Associação Nacional de Pós-Graduação e Pesquisa em Ciências Sociais (ANPOCS), um grupo de trabalho sobre Cultura Brasileira em que participaram, entre outros, Maria Isaura Pereira de Queiroz e Renato Ortiz .

Ana: Lembro, ainda como aluna do Programa de Pós-Graduação em Antropologia Social, que este grupo de Cultura Brasileira acabou se tornando um clássico dos encontros da ANPOCS, no início dos anos 80, e que, hoje, aparece como uma tradição de pensamento.

Ruben: Sim, é um grupo que tem uma tradição importante. O seu primeiro seminário foi em Ouro Preto, em 1980, chamando-se “Cultura Brasileira?”. A idéia inicial era problematizar o que era isso que se chama de cultura brasileira, daí o ponto de interrogação no título. Depois, fizemos vários outros seminários, já sem o ponto de interrogação. O grupo havia, então, se formado e foi um grupo que teve uma quantidade enorme de trabalhos que foram discutidos lá. No grupo nós discutíamos desde o que era a cultura brasileira, identidade, até trabalhos pontuais, sobre lazer... Foi um grupo que produziu muitas publicações, inclusive. Lembro que as pessoas sempre me diziam: "Ah, são interessante essas coisas”. E isto trouxe uma série de interrogações sobre cultura brasileira e inclusive depois sobre a cultura gaúcha. As pessoas me diziam: "Mas afinal, 
tu és gaúcho, como é essa história da cultura gaúcha?” E para ser bem sincero, eu não entendia nada de cultura gaúcha. Eu conhecia o mundo todo, tinha viajado para os Estados Unidos, conhecia toda a Europa, tinha visitado à Ásia, conhecia, relativamente bem, muitas das grandes cidades brasileiras, mas do Rio Grande do Sul eu não conhecia nada. Nunca tinha vivido no interior, e conhecia relativamente pouco. Então, eu me disse "vou começar a mexer com isso". E aí aconteceram assim, duas coisas. Uma é que neste exato momento começou a haver o renascimento das tradições gaúchas. Se na década de 70 todo mundo dizia que os gaúchos estavam desaparecendo, se tu quisesses ver um gaúcho, em Porto Alegre, tu tinhas que ir na rodoviária, porque era um cara que veio da Campanha, meio "perdidão" e que não se atreveria a ir até a Rua da Praia; nos anos 80, justamente, há um renascimento enorme das coisas gaúchas. Festivais de música nativista, discos nativistas, restaurantes, jornais, revistas, livros, lojas de roupa, tudo voltado para o cultura gaúcha. De repente me dei conta do que estava acontecendo e que valia a pena estudar isso. Bom, aí tive de estudar seriamente a história do Rio Grande do Sul e comecei a estudar feito um louco, pesquisar, ler... Me dei conta de quão pouco eu sabia e, realmente, fui estudando a fundo. Criei, um seminário de um semestre no nosso programa de pós-graduação sobre "Sociedade e Cultura no Rio Grande do Sul”. E descobri que havia muita gente do Rio Grande do Sul que também não sabia quase nada da história do Rio Grande do Sul. E, de repente, as pessoas começaram a perguntar: "Como é que tu sabes isso, como é que tu sabes aquilo?” Havia uma reação das pessoas que era muito interessante. Elas brincavam comigo: “Oh, agora que tu vais estudar a cultura gaúcha, tu vais botar bota? Vais andar a cavalo?” Mas eu percebi que por detrás do humor, e o humor é uma forma de se falar de coisas difíceis, as pessoas estavam com alguma dificuldade em considerar que esse era um tema válido de estudo em antropologia. Era importante mas parecia, sei lá eu, “coisa de grosso”! Uma segunda coisa que ocorreu era que muitas pessoas me admoestavam, diziam algo assim: "Tu já tens um nome nos estudos de Cultura Brasileira e, agora, tu estás regredindo, indo para o regional”. E eu sempre dizia: "Eu não estou regredindo, não estou indo para uma coisa menor, estou indo para uma coisa maior, estou estudando um fenômeno que é universal.” Nessa época, nem se falava em globalização... Eu respondia: "Olha, eu acho que o mundo inteiro está redescobrindo o local. E depois, quando começou a surgir o caso da Iugoslávia, eu confirmei que tinha ainda mais razão de estudar o regional, o local. 
Desde o começo eu tinha interesse no Rio Grande do Sul, mas não queria ficar só no Rio Grande do Sul pelo Rio Grande do Sul, não queria ser mais um especialista em Rio Grande do Sul, isto é, "as bombachas tem que ter botão ou não tem que ter botão, como é que é?”. Eu queria conseguir compreender o que estava significando o renascimento do tradicionalismo... Eu queria saber o que era, afinal, isso?”.

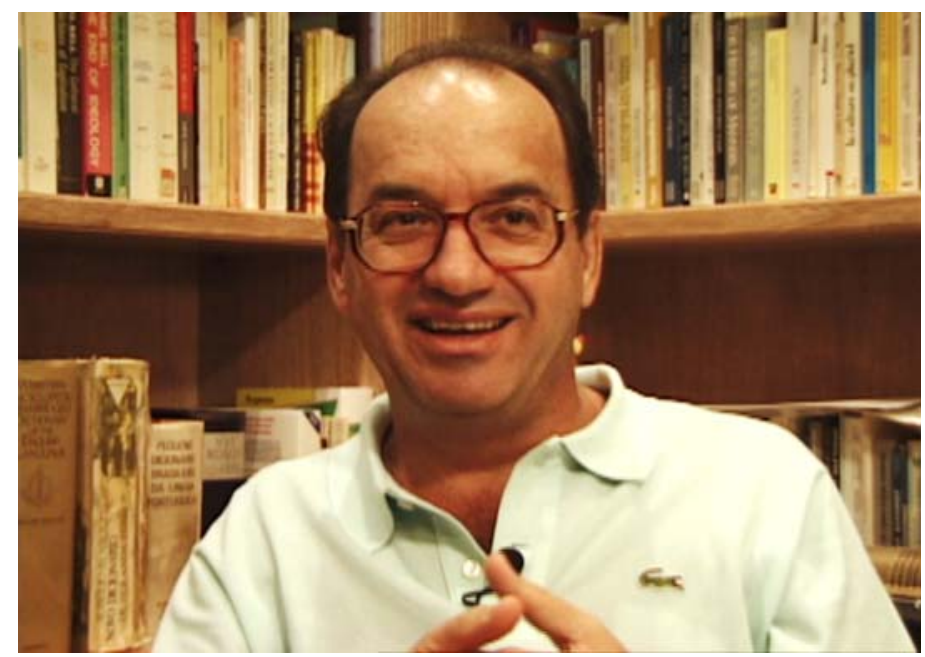

Ana: Esta busca de compreensão do tradicionalismo no RS e em Porto Alegre, remete a algumas de tuas preocupações anteriores no que tange às fronteiras entre campo e cidade, rural e urbano, agora sob a feição do aparecimento das fronteiras culturais, não?

Ruben: Bom, aí, na verdade é que eu me dou conta que o regional é um tema muito importante no Brasil e que havia toda uma discussão a respeito de como se pensa o Brasil. Uma tendência, sempre unitária, era a de que o Brasil tem que ser unificado, isto é, temos que construir a brasilidade e jamais se poderia apontar para as diferenças. Bom, a outra tendência é dizer que o Brasil era muito grande e que ele tinha que ser pensado regionalmente. Algumas pessoas falavam sobre isso, inclusive Gilberto Freyre apresentou o Manifesto Regionalista falando sobre isso. Sempre havia uma tensão ... por exemplo, Monteiro Lobato tem um livro chamado América, em que ele revela uma preocupação com a 
possibilidade de o Brasil se desmembrar e dá como exemplo justamente o Rio Grande do Sul.. O Rio Grande do Sul, pelo fato de ser um estado de fronteira, de ter passado por uma revolução que proclama a República de Piratini, era o lugar ideal para se estudar isso.

Ana: O tema da heterogeneidade cultural do Brasil e dos regionalismos sempre sob o ponto de vista das suas implicações em torno da problemática da construção do nacional.

Ruben: É isso. Eu decidi abraçar a questão de o Rio Grande do Sul ser visto como um estado diferente. Tudo o que vinha se dizendo, nos anos 70, do tipo "o Brasil está ficando todo igual”, e o Rio Grande do Sul seria um exemplo deste processo, nos anos 80 se revela questionável, pois a realidade mostrava que as coisas não eram bem assim. As pessoas diziam: "Eu sou brasileiro, mas eu sou brasileiro gaúcho, e isso é muito importante, e eu vou afirmar as minhas peculiaridades". Claro que se trata de uma peculiaridade recriada, pois são pessoas que moram em cidades. O Rio Grande do Sul já era um estado eminentemente urbano, estava se industrializando rapidamente. Mas o que se recria é uma tradição rural, era reinventar uma tradição rural, o que está acontecendo também agora, com festa de peão boiadeiro. E por que o Brasil, quando já está urbanizado, reafirma isso? Quer dizer, quando o Brasil está passando pelo processo de urbanização, nos anos 50/60/70, ele não quer falar do rural. No momento em que o país já se urbanizou, então, ele começa a falar de algo que não está desaparecendo, mas diminuindo. Bom, ao falar, assim, do regional, eu estou falando do nacional, mas falo também de um fenômeno que é internacional, isto é, o fato de que no mundo todo, principalmente na Europa, as diferenças regionais estão o tempo inteiro tentando ocupar um espaço ... os catalães ou bascos, na Espanha, os irlandeses, os bretões ... Bem, em alguns casos, disto derivam conflitos étnicos, que é o caso da Iugoslávia ... e aí de novo eu noto que tem uma preocupação política. Se a antropologia pode contribuir para que as pessoas diminuam as guerras que aconteceram ao longo do século passado, durante o século XX, ela se torna importante para que se possa dar conta de que existem diferenças culturais e que a diferença tem que ser negociada. Então, em primeiro lugar, o mundo não está ficando todo igual, ele está ficando assim apenas num nível, quer dizer... retomo aquela antiga discussão que havia sobre a urbanização, sob outros aspectos. E me dou conta de que sempre se volta para os antigos amores. Assim, se o mundo está ficando uniforme em 
algumas coisas, (os fast foods, a MTV, a tecnologia, a Internet), e tudo isso unifica, ao mesmo tempo, e talvez até por esta razão, as pessoas estão o tempo inteiro afirmando: "Eu tenho coisas diferentes”. As diferenças culturais são importantes, têm que ser reconhecidas e, se elas não são reconhecidas, eu estou disposto a morrer e matar por elas ... então, hoje há a necessidade de se construir pactos, o que é um pouco o caso da União Européia. Quer dizer, são países que passaram se matando durante séculos e que fazem um acordo, no começo, um pacto econômico, tarifário ... e o que mais me impressiona é a idéia de que todos os conflitos, e não são poucos, têm que ser resolvidos pela negociação, cada vez menos através das armas. Um processo lento, demorado, mas fundamental. Então, em última análise, acho que esse estudo que eu acabo fazendo, é um pouco uma contribuição que a antropologia dá para esse tipo de debate. E é, também, pensar o Brasil. Então, o estudo do Rio Grande do Sul foi um pouco por aí... ele me conduz à cidade porque acabo estudando o Movimento Tradicionalista Gaúcho, composto por pessoas que vieram do campo para cidade, e dizem, explicitamente, quando os entrevisto, que eles se sentiam perdidos na cidade. Alguns deles haviam lido as produções da Escola de Chicago, falando sobre a desagregação, o isolamento, o anonimato ... e eles concordavam com o diagnóstico da Escola de Chicago. Só que a solução deles não são as idéias da Escola de Chicago, mas o tradicionalismo. Então, novamente, estou lidando com a categoria cidade, já entrando numa outra área, o que me interessa muito hoje que é a circulação entre idéias eruditas e idéias populares. Quer dizer, como é que o conhecimento erudito vira senso comum? Como é que o Gilberto Freyre é repetido por pessoas que nunca o leram? Quer dizer, como se dá essa passagem? Não só o pensamento de Gilberto Freyre, do positivismo, de outras idéias. Bom, é retornar à discussão se as idéias estão fora do lugar ou não, que é uma discussão muito antiga. Começo, então, a trabalhar com a idéia da desterritorialização ... e, daí, eu noto que a cultura gaúcha se desterritorializa várias vezes. Ela sai da Campanha, atingindo todo o Rio Grande do Sul, inclusive a área de colonização alemã e italiana. Da mesma forma, ela é levada para fora do Rio Grande do Sul, ela viaja para Santa Catarina, Paraná ... e, depois, é levada para o exterior. Então, as idéias e os costumes viajam e vão se modificando sucessivamente, o que me conduz à questão do que é uma fronteira, ou seja, “como tu constróis uma fronteira numa época de globalização?” Por um lado, tu tens uma fronteira que é real, se eu for cruzar de um país para outro, eu preciso ter passaporte, documento de identidade, 
visto... Mas, por outro lado, as fronteiras estão cada vez mais dentro dos países. A própria noção de território, o que significa pertencimento, fica cada vez mais complicado, principalmente porque as pessoas viajam, e o Brasil é um exemplo disso, porque tem quase dois milhões de brasileiros já morando no exterior. Então, há uma interpenetração que faz com que a noção de fronteira fique mais difícil de ser precisada. Por que alguém que nasceu no Paraná, e foi criado lá, se sente, muitas vezes, mais gaúcho do que alguém que nasceu no Rio Grande do Sul? Estas coisas são complicadas porque, de alguma maneira, o gauchismo já se transplantou para lá.

Ana: De uma certa forma, este processo de desterritorialização presente no mundo contemporâneo complexifica o antigo conceito de cidade, produzido no âmbito da Escola de Chicago, no sentido de se precisar um fenômeno que ela própria já anunciava em seus estudos, ou seja, as múltiplas referências culturais dos grupos urbanos.

Ruben: Em outras épocas, havia uma tendência de demarcação mais clara entre campo e cidade, do tipo "isso é um comportamento urbano" e "isso é um comportamento rural”. Aos poucos, com as migrações, os comportamentos rurais vieram para a cidade e esta distinção ficou complicada. Hoje em dia, com o difusão da tecnologia, há uma tendência, que já existe nos Estados Unidos e que começa a aparecer no Brasil, de tornar a diferença entre o meio rural e o urbano menos marcada. Nos Estados Unidos tem muita gente que vive em grandes cidades como Nova York, Chicago e Los Angeles, mas tem também muita gente que vive em cidades pequenas, às vezes próximas às grandes cidades. As pessoas que vivem em pequenas cidades se comunicam com o resto do país. Eu posso ser um agente de viagem e, através do telefone, do fax, da Internet, vender passagens estando numa pequena cidade... No Brasil também está havendo outra coisa que é a reconstrução do campo. O Movimento Tradicionalista Gaúcho fez isso, mas o estilo country também o faz. Da mesma forma que o Movimento Tradicionalista Gaúcho fez com que a figura do gaúcho deixasse de ser a figura do grosso, como era vista na década de 70, ela passa, hoje, a ser chique, deixando de ser um estigma. O country recria uma coisa que é rural, mas vivenciada por pessoas da cidade e que às vezes leva as pessoas ao campo ... e, da mesma forma, o renascimento da tradição nas cidades brasileiras revigora o movimento no campo. A separação entre campo e cidade ficou mais complicada... no Brasil há um crescimento muito incipiente 
das cidades de tamanho médio. O estado de São Paulo talvez seja um exemplo. O interior de São Paulo forma o segundo mercado brasileiro, quer dizer, é um mercado mais forte que o da cidade do Rio de Janeiro. As pessoas percebem que não precisam mais morar numa cidade como São Paulo, que tem um custo econômico muito grande e, de repente, descobrem oportunidades de vida em cidades menores, o que cria uma rede mais espalhada no Brasil. No Rio Grande do Sul é mais difícil ver isto.

Ana: Esta tua discussão sobre, eu diria, a desterritorialização do conceito de cidade, acaba por te aproximar cada vez mais de uma discussão sobre a antropologia na América Latina, provavelmente, impensada nos anos 70 e, ao longo dos anos 80, com o processo de construção do nacional...

Ruben: Eu me lembro que quando eu era aluno de graduação, havia uma noção de América Latina, havia uma certa circulação de idéias em revistas. Isso, com a ditadura e a queda do governo Allende, parou. Eu sempre estive engajado no sentido de que a antropologia no Brasil formasse uma comunidade que fosse nacional e internacional ao mesmo tempo. O nosso programa do pósgraduação estabeleceu convênios com a França, com os Estados Unidos, mas muito pouco com as universidades da América Latina. Claro que existem razões para isto! As universidades brasileiras têm, comparativamente, muito mais recursos que as uruguaias e argentinas. O PPGAS conseguiu reverter este quadro um pouco a partir da criação das reuniões de antropologia no âmbito do Mercosul, surgida de reuniões, que eram dos programas de pós-graduação do sul do país, chamadas de “Abinhas”, que se transformaram nas Reuniões de Antropologia do Mercosul. A primeira, em Tramandaí, depois no Uruguai e a terceira, na Argentina. Em 2001 ela volta a acontecer no Brasil, em Curitiba. Isso cria a possibilidade de ter contato com antropólogos, principalmente, da Argentina e Uruguai. Começam a haver publicações de ambas as partes. No ano passado, a EUDEBA (Editorial Universitária de Buenos Aires) publicou meu livro, A Parte e o Todo, sobre os gaúchos e o debate da questão do local e do global, com o título de Nación y Modernidad. La reinvención de la identidad gaúcha en el Brasil. Anteriormente, a mesma editora já havia publicado o livro Caminhos da Adoção de nossa colega Claudia Fonseca.

Ana: Agora, repensando em todo esse processo de complexificação da tua produção intelectual ... A esta altura em que tu te encontras, isto é, na maturidade de tua produção científica, fico pensando como deve ser para ti acomodar 
uma série de coisas que tu fizeste... como é que tu dizias... ah, os teus "pecados de juventude" (risos).

Ruben: Não, não, pelo amor de Deus ... (risos) São pecados de juventude, mas eu assumo a paternidade inteiramente. São, aliás, os melhores pecados...

Ana: Tu pareces bem tranqüilo com estas idas e vindas que conformam o campo da tua produção intelectual. Nem sempre os intelectuais, ao chegarem na sua fase de maturidade, se relacionam bem com o seu passado...

Ruben: Eu sou uma pessoa que tendo a não jogar as coisas fora. Tenho uma quantidade enorme de livros na garagem. Não gosto de jogar coisas fora e, geralmente, quando eu jogo fora algum papel, algum artigo, na próxima semana estou precisando dele. Eu digo, “viu, eu não devia ter jogado fora!”(risos). Bom, eu tendo a incorporar tudo. Quer dizer, eu acho que todas as coisas que fiz foram importantes, não só no momento que fiz, mas principalmente depois. De alguma maneira, elas são incorporadas, são um aprendizado... Tenho a tendência a achar que temos que fazer o que podemos fazer naquele momento e da melhor maneira possível. Eu sou muito exigente comigo mas, por outro lado, tenho noção do que consigo fazer naquele momento. Bom, no momento, é isso que eu consigo fazer da maneira mais honesta e melhor possível. Por conseguinte, assumo todos os meus pecados (risos). E quando eu digo pecado, é pecado no bom sentido, no sentido gostoso da palavra.

Ana: E como é que fica o futuro... Em que coisas andas pensando?

Ruben: Tenho várias projetos; tenho muitas demandas que me fazem e que, de algum modo, eu me faço ao receber um convite. Deve sair um livro na Inglaterra sobre a questão da modernidade na América Latina, e a pessoa que está organizando me pediu para escrever um artigo sobre a modernidade nos trópicos. Bom, então, eu fiz um artigo sobre isso, "Brasil, o moderno nos trópicos”, e que eu não faria se não tivesse a demanda. Então, tem várias coisas deste tipo. Por outro lado, gostaria de publicar um livro sobre música popular brasileira, que já tem algumas partes escritas mas outras por escrever. A música é uma paixão imensa minha. Geralmente quando estou fazendo as coisas, eu já tenho uma intuição de que aquilo vai me levar para um outro lugar e sempre que eu termino uma coisa, preciso imediatamente engrenar noutra. Quer dizer, tenho sempre uma certa inquietude ... Deus me livre, se eu resolvi todos os 
meus problemas intelectuais ... um problema sempre está me levando a outro, que de algum modo já esta lá. Às vezes, não me dou conta, mas pensando retrospectivamente, eu digo "puxa, aqui eu já estou começando a ficar interessado nesse assunto, sem me dar conta que vai aparecer depois...” Então é uma mistura assim de razão e de intuição.

Ana: Interessante... Tu aceitas as coisas quando as pessoas te provocam com questões... Algumas pessoas reagiriam de outra forma, dizendo "ah, nem quero saber disso aí...”, mas tu, ao contrário, acha que há, na provocação, uma razão...

Ruben: Eu funciono muito com desafios. Gosto dos desafios... eu não fujo de desafios e, de alguma maneira, sou movido a isso. Quer dizer, estou sempre colocando metas, desafios e coisas... é um pouco o meu modo de funcionar. Se está tudo fácil, não tem graça (risos).

Ana: E esse processo foi o teu percurso intelectual dentro da antropologia, em especial com as tuas pesquisas anteriores e, provavelmente, se prolongou dando origem ao teu projeto de pós-doutoramento nos EUA.

Ruben: Fui fazer o pós-doutorado, em 93. A esta altura eu já tinha publicado o livro, em 92, A Parte e o Todo, e queria partir para outra coisa. Queria morar uma época nos Estados Unidos. Eu tinha morado e feito doutorado na Inglaterra; tinha passado vários períodos na França, pois quando terminei a tese de doutorado eu passei um período lá. Mas os Estados Unidos, eu só tinha visitado, nunca tinha morado. E queria ter um pouco uma experiência deste tipo e acabei indo para a Universidade da Califórnia em Berkeley. Foi uma experiência fascinante, bastante diferente da Inglaterra e da França ... Um ritmo de vida também completamente diferente, um bom contraponto com o Brasil. Quando fui para os Estados Unidos, no começo, eu não sabia muito bem o que ia fazer lá. Por um lado, queria ter tempo para estudar. A Universidade da California era fantástica! Mas quando fui para lá, alguns antropólogos americanos que me conheciam e ao meu trabalho disseram "ah, tu vais para os Estados Unidos, tu podias estudar os brasileiros em São Francisco, tem um número muito grande lá”... Mas este tema não me atraía em nada. Eu acho que quando o teu coração não vai para um lugar, não vai, porque não adianta... Eu sempre digo para os alunos "se tu não gostas de fazer uma coisa, não faz porque não vai dar". Achava que era isso que se esperava de um antropólogo do Terceiro Mundo, que ele estudasse o Terceiro Mundo no Primeiro Mundo. Eu disse não. Na 
época, estava fazendo uma pesquisa sobre a questão do dinheiro na música popular brasileira e tinha feito uma longa pesquisa no Museu da Imagem e do Som, do Rio de Janeiro, e que resultou num artigo publicado na Revista Brasileira de Ciências Sociais. E, de repente, eu disse: "Pô, os Estados Unidos é o país do dinheiro, eu podia estudar o dinheiro nos Estados Unidos”. Mas foi um pouco, assim... não era nem pecado da juventude, era um delírio: "Eu vou estudar o dinheiro nos Estados Unidos"(risos). Ao mesmo tempo, eu me dizia "Ruben, que coisa louca”. Mas o meu coração ia por aí, então eu me disse "é isso que eu vou fazer”. Quando cheguei nos Estados Unidos e disse que estava interessado em estudar o dinheiro, eles tinham uma reação muito gozada. Uns diziam assim “ah, que interessante, o dinheiro aqui nos Estados Unidos...”, e perguntavam “mas, como é que tu vais estudar isso?”. Bom, eu respondia que não sabia, e eles me olhavam meio estranho... eu mesmo achava que estava embarcando "numa fria". Mas devido ao fato de estar com o olhar atento e flutuante, comecei a prestar atenção e notei que estava mergulhando numa sociedade em que tudo é dinheiro, tudo passa pelo dinheiro... Comecei a notar como isso permeava todo o cotidiano, desde a experiência de abrir uma conta bancária nos Estados Unidos, o que ela envolve, as escolhas, etc. E como todas as coisas eram diferentes do Brasil! Bom, de repente, me dei conta de que tudo era dinheiro ... Eu ia nas livrarias ... e tinha uma seção inteira sobre "personal finance"... Então, comecei a estudar várias instâncias diferentes ... Eu fiz uma pesquisa entre devedores anônimos e achei coisas que não terminavam mais, acabei produzindo um artigo que se chama "Looking at Money in America". Mas América, propositadamente, em dois sentidos: a América do Norte, que é como os americanos se referem aos Estados Unidos, e as Américas, porque era um artigo escrito por um antropólogo latino-americano que chega em um outro país e resolve empregar o método etnográfico para estudar a metrópole, e resolve estranhar o que para eles é familiar. O interessante é que fui convidado várias vezes para apresentar trabalhos sobre o tema nos Estados Unidos, e a reação das pessoas eram diversas. Primeiro eles riam muito, riam muito porque se viam identificados. Segundo, as pessoas depois vinham falar comigo e quase se desculpavam: "Tudo o que tu falaste está certo. Mas tu deverias ter morado nos Estados Unidos na década de 60, tinha os hippies, a gente não se interessava tanto por dinheiro”. Bom, este artigo, quando eu fui publicar decidi que iria fazê-lo nos Estados Unidos. Mandei ele para várias revistas, e ele foi recusado. Então era um pouco assim: "não queremos ser estudados por pessoas de fora". $\mathrm{O}$ artigo acabou sendo publicado numa revista que se chama Critique of 
Anthropology, uma revista internacional que procura artigos desse tipo. Quer dizer, no fundo eu estou pensando nos Estados Unidos, mas também estou pensando no Brasil. Pois nos Estados Unidos, dinheiro é uma coisa que se fala com a maior naturalidade, porque, ao entrar num restaurante, tu és recebido pelo maître que te diz "nós temos um prato novo" e te descreve todo o prato e, ao final, diz "custa catorze dólares e setenta e cinco cents", coisa que, no Brasil, tu dirias "pô, que coisa de mau gosto, eu não quero saber o preço agora, depois eu vou olhar”. No Brasil, de preferência tu tens que falar de dinheiro sem mencionar a palavra dinheiro. Quer dizer, “eu estou sem nenhum”... tu não dizes "estou sem nenhum dinheiro, mas diz "estou sem nenhum" ... porque o dinheiro é uma coisa que prostitui. Ou, então, tu dizes "estou sem um puto tostão” porque o dinheiro é uma coisa prostituída, então ela é suja. E, em inglês, é o contrário, tem vários provérbios que falam do dinheiro como uma coisa limpa, inclusive, tem um provérbio que diz assim: "Todo o dinheiro é limpo, mesmo quando ele é sujo”. Eu peguei várias perspectivas ... discuto protestantismo, catolicismo, individualismo, procurando discutir, inclusive, o dinheiro como um fato social total, o que me leva, digamos, a uma outra coisa que estou muito interessado que é compreender o Brasil que se transforma rapidamente em uma sociedade de consumo. Como é que funciona o consumo num país que tem diferenças econômicas e sociais tão marcantes? Até que ponto o consumo não é um fato cultural? Então, isso é uma das coisas que eu também estou interessado, hoje, em estudar.

Ana: Vou me deter nas tuas premiações ... Em especial, na premiação da ANPOCS, em 93, ao teu livro A Parte e o Todo... qual foi o significado que isto teve na tua vida profissional?

Ruben: O livro saiu em 92. Foi publicado com o título de $A$ Parte e o Todo, e a idéia era discutir o Brasil, que seria o todo, e a parte, que seria o Rio Grande do Sul. Ele contempla toda uma parte teórica sobre a nação e a tradição na virada do milênio e as razões de seu ressurgimento hoje. Tem um capítulo que discute o nacional e o regional no Brasil e outro versando sobre a relação do Rio Grande do Sul com o Brasil. Depois, tem um capítulo dedicado ao tema do Movimento Tradicionalista Gaúcho e um outro que se chama "A Polêmica Identidade Gaúcha”, e que trata da construção social da identidade gaúcha, onde discuto quais são as polêmicas que existem sobre isto. Há, ainda, um pequeno capítulo de encerramento que se chama “Novas Fronteiras da Cultura”, apon- 
tando para o problema das fronteiras. Eu estava nos Estados Unidos, na Universidade da Califórnia, em 93, e fiquei muito contente em saber que o livro havia ganhado o prêmio de melhor livro em Ciências Sociais no Brasil dado pela ANPOCS. O livro acabou sendo publicado nos Estados Unidos com o nome de Tradition Matters: modern gaúcho identity in Brazil, pela Universidade de Columbia, e foi, agora, publicado na Argentina. Isso é bom não só do ponto de vista da satisfação pessoal, mas também porque atinge públicos diferentes. É obvio que o público que lê em inglês, não lê em português, e se o livro não está traduzido, ele não lê. Eu até recebo comentários pela Internet de pessoas que leram o livro em inglês. Esta é uma coisa com a qual nós, aqui no PPGAS, nos preocupamos muito, isto é, ampliar o acesso às produções que vêm sendo feitas. De algum modo, nós fizemos isso através da revista Horizontes Antropológicos. Quando a revista surgiu, decidimos que cada número seria temático e que publicaríamos em quatro línguas: português, espanhol, inglês e francês. É uma revista que surgiu internacional, não só pelas línguas, mas por publicar artigos de especialistas no tema. Isso recria um postura que foi, desde a época da criação de nosso Curso de Especialização em 1974, a nossa preocupação com a antropologia que fazemos aqui no Rio Grande do Sul. Desde o começo queríamos ser um centro de produção que não fosse meramente local ou regional. Por isto sempre achamos importante ter contatos com antropólogos de outros centros do Brasil e do mundo. A primeira turma de alunos de nosso Curso de Especialização teve aulas com professores nossos, mas também de outras partes do Brasil, dos Estados Unidos e da Inglaterra. Convidamos para nossas bancas examinadoras de dissertações e teses professores de fora. Além de termos uma avaliação externa, isto possibilita um rico intercâmbio cultural que agora também está se desenvolvendo em direção ao Mercosul, de onde vêm professores e alunos para nosso Programa. Desde o começo do surgimento do PPGAS nós achamos que esta noção de centro e periferia não tem lá muito sentido.

Ana: Pensar a produção intelectual do PPGAS no sul seria até um contrasenso no que diz respeito à forma como tu concebes a diversidade dos próprios fenômenos culturais. Pensar, assim, no plano de uma reflexão da conformação do campo da antropologia no RS seria, sob muitos aspectos, incoerente.

Ruben: Sempre achamos que Porto Alegre é um lugar tão central quanto São Paulo e Rio de Janeiro. Se a gente pensar em termos do Mercosul, constatare- 
mos que a centralidade está sendo repolarizada, os antigos “centros" cedendo lugar a novos "centros". Vão sendo formuladas novas construções de lugares... nunca chegou a nos preocupar o fato de estarmos situados no sul do país. Nos Estados Unidos isso é muito comum, excelentes universidades estão em cidades minúsculas, como Princeton, e ninguém vai dizer que o lugar é provinciano, pois as pessoas que estão lá estão pensando coisas amplas. O que conta não é o fato de o lugar ser pequeno ou não, mas o que as pessoas fazem neste lugar. De alguma maneira, a revista Horizontes Antropológicos se soma a esta idéia. Esta revista tem uma penetração relativamente grande em outros países... ela circula, é assinada, comprada, doada e, desde o começo, teve uma perspectiva aberta, pois não era uma revista para escoar a nossa produção. Por isso, em parte, ela tem essa aceitação e penetração.

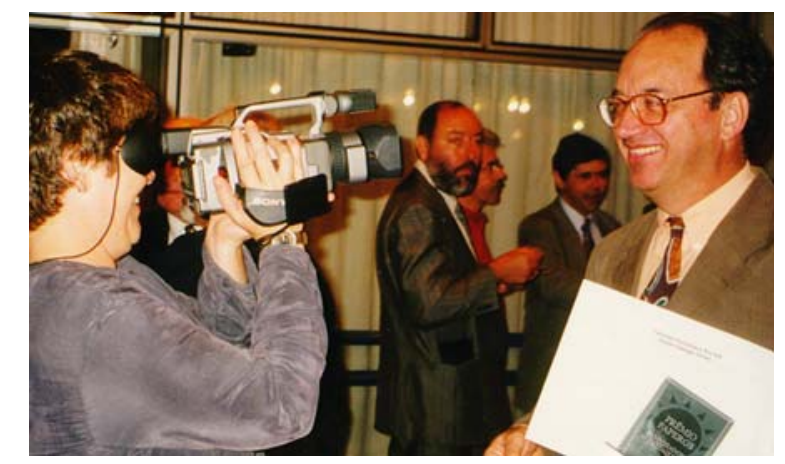

Professor Ruben G. Oliven e Ana Luiza Carvalho da Rocha - Prêmio Pesquisador Destaque FA.PERGS/1998. Acervo pessoal

Ana: E os outros prêmios que recebeste, em 98, um como Pesquisador Destaque nas Ciências Humanas e Sociais, que te foi atribuído pela FAPERGS, e o outro, em razão do conjunto geral de tua produção sobre a cultura brasileira?

Ruben: A FAPERGS fez uma coisa muito interessante ... resolveu criar um prêmio, em doze áreas da ciência, com a finalidade de premiar um pesquisador por área por sua produção nos últimos dois anos ligada ao Rio Grande do Sul. O júri é composto por pessoas de fora. Meus colegas acharam que eu, nos últimos dois anos, tinha tido a maior produção em relação ao Rio Grande do Sul, 
tendo um livro publicado nos Estados Unidos e, ainda, vários artigos, e lançaram meu nome. Eu tive a felicidade de ganhar um prêmio que dá direito de participar de qualquer congresso em que eu tivesse um trabalho aceito. Assim é que eu vou conhecer, este ano, a Beijin para apresentar um trabalho sobre culturas metropolitanas, organizada pela Associação Chinesa de Antropologia Urbana, e para conhecer a China, um grande sonho meu. É bom porque o prêmio se institucionaliza ... e cada ano uma pessoa é premiada, marcando-se o reconhecimento da comunidade em relação a pesquisadores que trabalhavam com a questão do Rio Grande do Sul. O outro prêmio que ganhei em 1998 é o Prêmio Érico Vannucci Mendes. É um prêmio que uma pessoa adorável, a Dra. Marta Vannucci, uma pesquisadora morando atualmente na Índia, uma das maiores especialistas em manguezais e oceanos, instituiu para lembrar seu filho que faleceu nos anos 80. Ele era um grande produtor cultural, e para manter a memória dele, ela lançou um prêmio que é dado para pessoas que contribuíram para o estudo da cultura brasileira. Esse prêmio é atribuído para produtores culturais, escritores, pesquisadores, através de um júri composto por pessoas do Ministério da Cultura, SBPC e CNPq. No mesmo ano, em 98, acabei ganhando dois prêmios, um deles, pelo estudo da cultura gaúcha e, o outro, pelo conjunto da minha obra no que diz respeito à cultura brasileira. Este último prêmio é dado por ocasião da reunião anual da SBPC. A pessoa que ganha é obrigada a dar uma palestra sobre sua obra... é interessante...

Professor Ruben G. Oliven e Dra. Marta Vannucci - 50 SBPC - Prêmio Érico Vannucci Mendes/1998. Acervo Pessoal

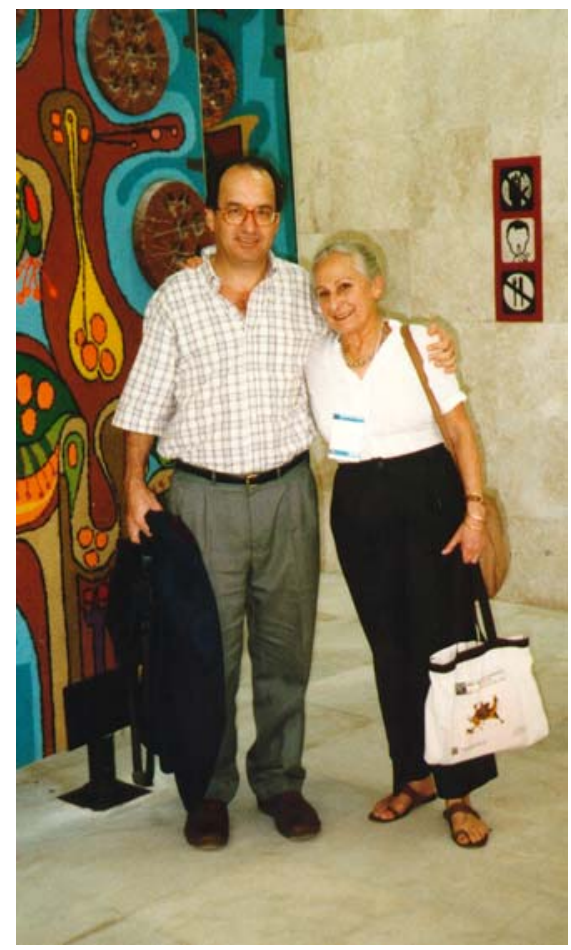




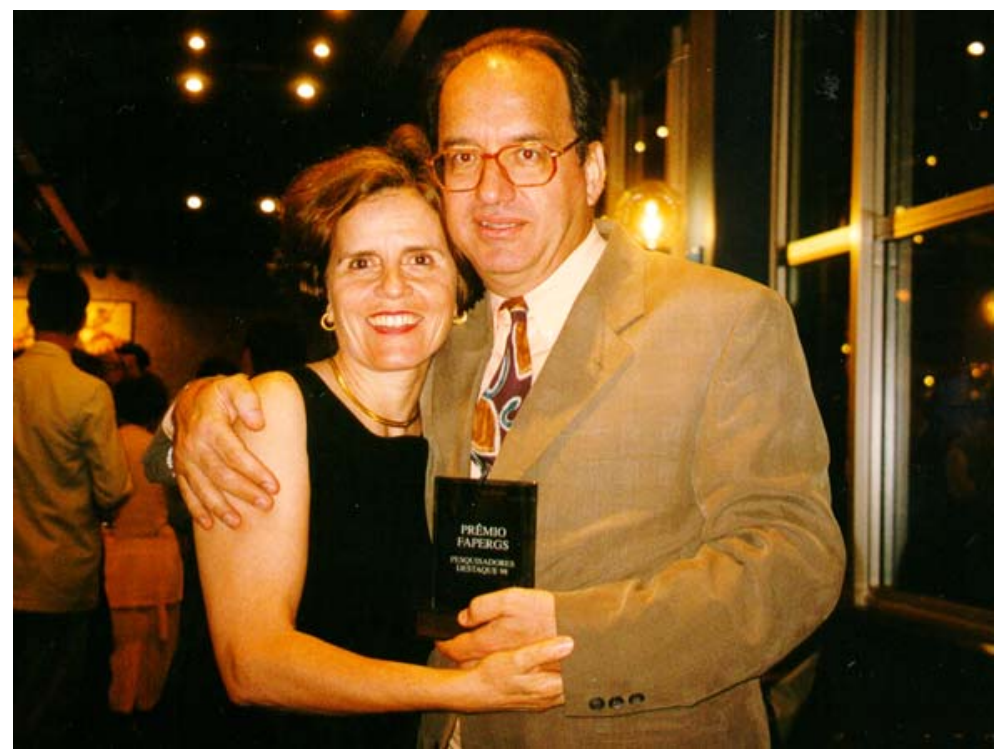

Professor Ruben G. Oliven com sua esposa Arabela - Prêmio Destaque FAPERGS/1998. Acervo pessoal

Ana: E o que estes prêmios te permitem, hoje, refletir sobre a tua obra?. Isto é, estes prêmios podem te possibilitar um balanço das formas através das quais tu vens orientando a tua prática intelectual?

Ruben: Ao dar a palestra, por ocasião do recebimento do Prêmio Érico Vannucci Mendes, o que eu fiz foi pagar um tributo a todas pessoas que me possibilitaram ser o que sou. Comecei agradecendo a meus pais e ao modelo que eles foram em termos de educação e dos incentivos que me deram, e continuei agradecendo a minha mulher Arabela, que também é cientista social e com quem discuto meus trabalhos, a meus professores e a meus colegas. Eu procurei mostrar que um prêmio, apesar de ser uma coisa individual, no fundo, é sempre uma coisa coletiva. Ninguém faz chover sozinho, e crescer significa crescer sempre junto com o grupo. 


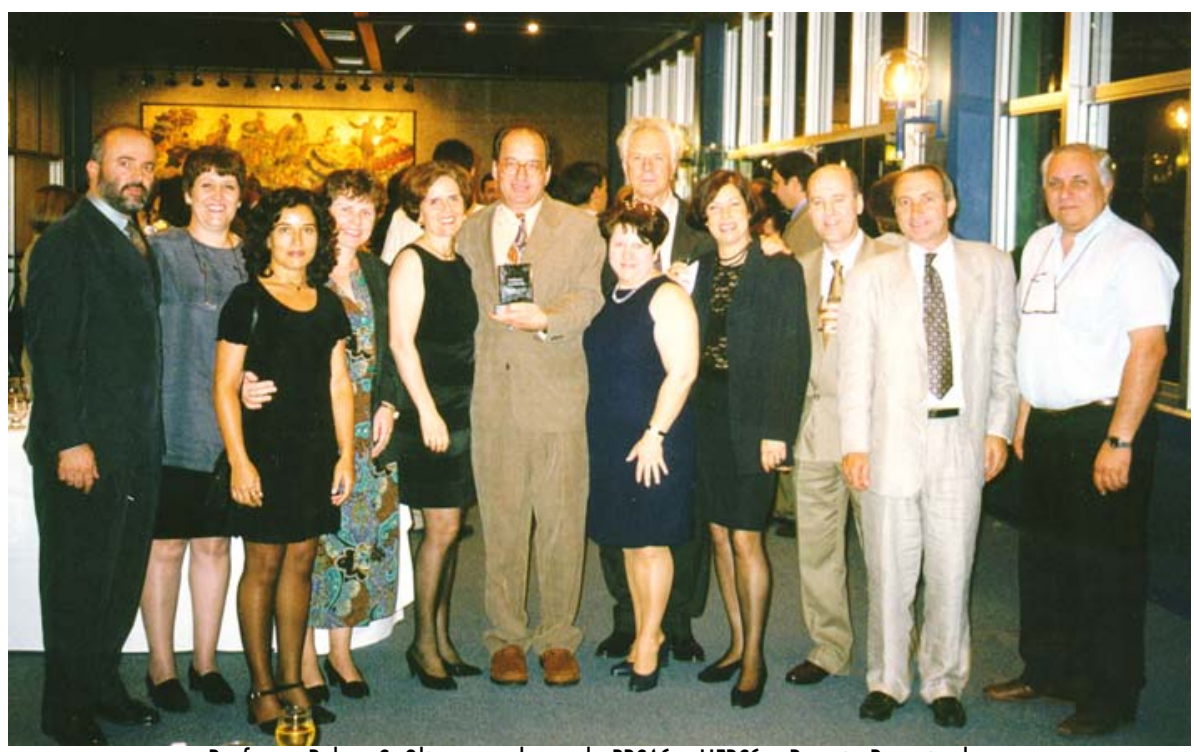

Professor Ruben G. Oliven e colegas do PPGAS - UFRGS - Prêmio Pesquisador

Destaque FAPERGS/1998. Acervo pessoal

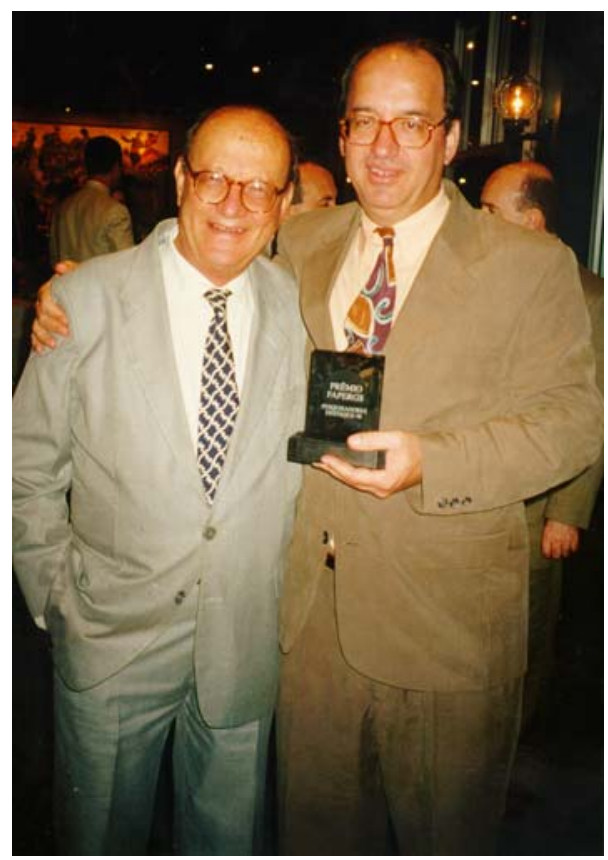

Professor Ruben G. Oliven com seu pai, Klaus Oliven

- Prêmio Pesquisador Destaque FAPERGS/1998. Acervo pessoal 